\title{
EFFECT OF MORPHODYNAMICS ON ANNUAL AVERAGE ZONATION PATTERN OF BENTHIC MACROFAUNA OF EXPOSED SANDY BEACHES IN SANTA CATARINA, BRAZIL
}

\author{
Eliana dos Santos Alves ${ }^{l}$ and Paulo Ricardo Pezzuto ${ }^{2, *}$ \\ ${ }^{1}$ Instituto de Biociências da Universidade de São Paulo \\ Doutorado em Ecologia \\ (Rua do Matão, 321, 05508-900 São Paulo, SP, Brasil) \\ lialves@lycos.com \\ ${ }^{2}$ Centro de Ciências Tecnológicas da Terra e do Mar - Universidade do Vale do Itajaí \\ (Rua Uruguai, 458, 88.302-202 Itajaí, SC, Brasil) \\ pezzuto@univali.br \\ *Corresponding author: pezzuto@univali.br
}

\begin{abstract}
A B S T R A C T
This study investigated the effect of environmental factors on the annual average zonation pattern of benthic macrofauna of sub-aerial profile of three exposed sandy beaches of Santa Catarina with different morphodynamic characteristics. Sampling was carried out between March 2000 and March 2001, with monthly frequency on reflective and dissipative morphodynamic extremes and bimonthly frequency on the intermediate state. Results showed that macrobenthic zonation presented marked differences across the morphodynamic spectrum. The main differences observed from reflective to dissipative conditions were: a) increase in the number of species in lower zones of the beach; b) expansion of zones characterized by high water content of sediment and c) increase in the overlapping of zones, mainly on lower levels of the beach. Canonical Correspondence Analysis related these differences to distinctive cross-shore gradients in sediment moisture levels, sediment reworking and mean grain size that exist across the morphodynamic spectrum, showing that it is important to analyze these environmental factors in studies conducted to investigate zonation on microtidal exposed sandy beaches.
\end{abstract}

\section{RESUMO}

Este estudo analisou o efeito dos fatores ambientais sobre a zonação da macrofauna bentônica da porção subaérea de praias arenosas expostas e caracterizadas por diferentes estágios morfodinâmicos em Santa Catarina. As amostragens foram realizadas entre março/2000 e março/2001, a intervalos mensais nos extremos morfodinâmicos e bimestrais no estágio intermediário. Os resultados obtidos demonstraram que a zonação da macrofauna bentônica apresentou as seguintes diferenças, do extremo refletivo para o dissipativo: a) aumento do número de espécies nos níveis inferiores da praia; b) aumento da extensão das zonas faunísticas caracterizadas por elevado teor de umidade do sedimento; e c) aumento da sobreposição das zonas faunísticas, principalmente, nos níveis inferiores da praia. Os resultados da Análise de Correspondência Canônica mostraram que estas diferenças resultam dos distintos gradientes verticais de umidade, remobilização sedimentar e tamanho médio de grão existentes ao longo do gradiente morfodinâmico, demonstrando a importância de analisar estas variáveis em estudos dedicados a investigar os padrões de zonação de praias arenosas expostas e de micromaré.

Descriptors: Sandy beach, Zonation, Benthic macrofauna, Morphodynamics, Brazil.

Descritores: Praia arenosa, Zonação, Macrofauna bentônica, Morfodinâmica, Brasil.

\section{INTRODUCTION}

Macrobenthic zonation on sandy beaches is not nearly as visible and sharply defined as on rocky shores, but their existence is a distinctive feature and has been broadly documented (MCLACHLAN; JARAMILLO, 1995). The majority of studies conducted on this topic have been limited to describing and comparing the macrobenthic distribution patterns in accordance with the general schemes proposed by Dahl (1952) and Salvat (1964). The ecological factors and processes that generate and maintain zonation patterns have not been systematically investigated.

Despite the recognized role of the morphodynamic gradient on the spatial structure and temporal dynamic of the benthic macrofauna (JARAMILLO et al., 1993; MCLACHLAN; JARAMILLO, 1995; GIMÉNEZ; YANNICELLI, 1997; DEFEO; MCLACHLAN, 2005), this aspect has 
not been taken sufficiently into consideration for the understanding of the zonation of sandy beach macrofauna. The majority of studies are based on a single sampling and/or are restricted to investigating the effect of just a few environmental factors on the establishment and maintenance of the zonation across the morphodynamic gradient (e.g. JARAMILLO; GONZALEZ, 1991; DEFEO et al., 1992; JARAMILLO et al., 1993; BORZONE et al., 1996; GIMÉNEZ; YANICELLI, 1997; VELOSO; CARDOSO, 2001; BORZONE et al., 2003).

According to Brazeiro and Defeo (1996) and Defeo and McLachlan (2005), as faunal zones are dynamic, temporal studies are needed in order to obtain a representative picture of zonation patterns in microtidal sandy beaches, requiring intensive sampling to provide unbiased estimates. Futhermore, beaches with different morphodynamic states are characterized not only by distinctive cross-shore environmental gradients, but also by a distinctive dynamic. This is particularly true in relation to the extent of sediment reworking or accretion-erosion dynamics (SHORT, 1999), a factor which has so far been ignored by zonation studies.

This study carried out a one-year temporal monitoring of exposed microtidal sandy beaches with different morphodynamic states in order to: a) identify the mean cross-shore environmental gradients associated with the different morphodynamic types, including the extent of sediment reworking that benthic macrofauna experience on the different beach levels; b) identify the mean zonation patterns of the benthic macrofauna through the morphodynamic spectrum, and c) evaluate the effect of the environmental gradients associated with each morphodynamic state, and their accretion-erosion dynamics on the mean zonation pattern of the benthic macrofauna.

\section{Methods \\ Study Area}

Three microtidal sandy beaches located on the coast of Santa Catarina State $\left(26^{\circ} 30^{\prime} \mathrm{S}\right.$ and $\left.27^{\circ} 20^{\prime} \mathrm{S}\right)$ were selected for this study (Fig. 1). These beaches are exposed to wave action and have a N-S orientation but represent different morphodynamic types (KLEIN; MENEZES, 2001).

Taquaras is a reflective beach with moderately well sorted to well sorted coarse sands $(0.72$ to 0.92 $\mathrm{mm})$. It is characterized by a steep slope profile $\left(10^{\circ}\right)$ and deep water table. It is subject to high sediment reworking along the year and can present scarps of 2 $\mathrm{m}$ height during storm events (KLEIN; MENEZES, 2001; KLEIN et al., 2002; ALVES et al., 2004). It has a parabolic plan form and its shoreline is $920 \mathrm{~m}$ long, but it is located on a beach arc of $1,570 \mathrm{~m}$ in length together with Taquarinhas (a beach with similar sedimentary and morphodynamic characteristics). These two beaches are separated by a rock outcrop that extends $10 \mathrm{~m}$ offshore and which does not interrupt the continuity of the shoreline. In fact, Taquaras/Taquarinhas are technically considered to be part of one and the same beach system (KLEIN et al., 2002).

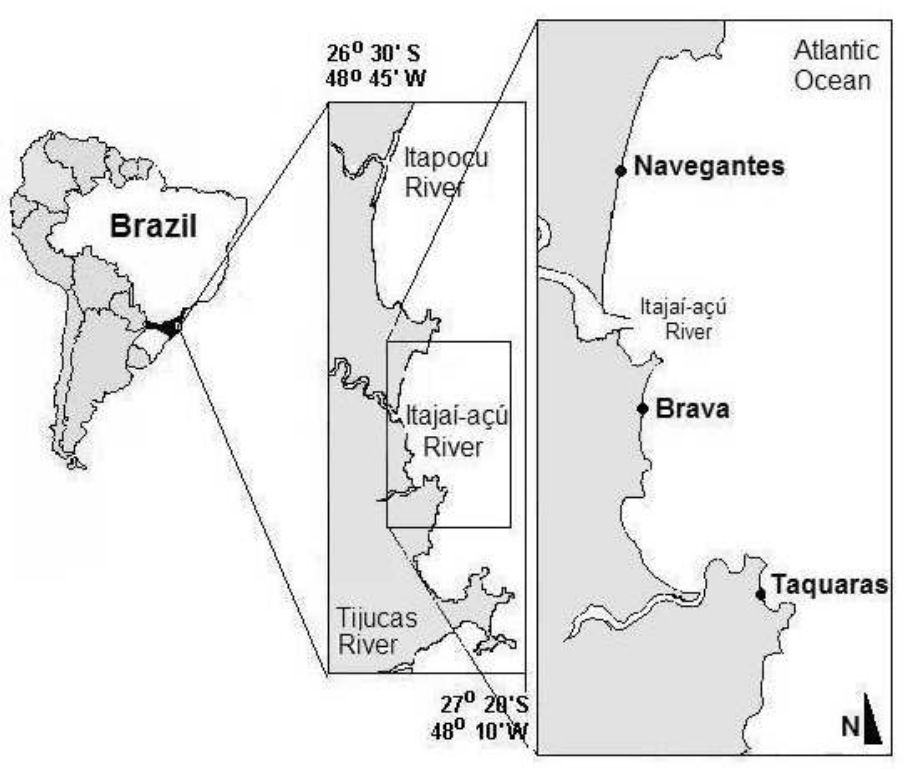

Fig. 1. Study area and location of sampling sites. 
Brava is an intermediate beach with moderately well sorted medium sands $(0.28$ to 0.34 $\mathrm{mm})$ and its beach face slope varies from $4.5^{\circ}$ to $6.5^{\circ}$. Its shoreline is $2,645 \mathrm{~m}$ long and its surf zone is $68 \mathrm{~m}$ in width, with bars and rip currents (KLEIN; MENEZES, 2001).

Navegantes is a dissipative beach with well sorted fine sands $(0.15$ to $0.19 \mathrm{~mm})$ and gentle slope profile (2.5 to 3.5$)$. It is subjected to low to moderate sediment reworking during the year and has very highly developed frontal dunes. Its surf zone is $83 \mathrm{~m}$ in width with a multiple-bar system and its shoreline is $10,030 \mathrm{~m}$ long (KLEIN; MENEZES, 2001). The Itajaí-açu River flows into the sea at the southern extremity of the beach, influencing coastal water salinity that varies from 22 to 36 through the year (SCHETTINI et al., 1999; SCHETTINI, 2002; ALVES et al., 2004).

Because of their distinctive environmental characteristics, these beaches' richness and abundance of benthic macrofauna differ markedly. Taquaras presents a reduced number of species (9), almost exclusively crustaceans. The isopod Excirolana braziliensis is the most abundant species (156.2 org. $\mathrm{m}^{-2}$ ) and represents $81 \%$ of the total macrofauna. Emerita brasiliensis (24.5 org. $\left.\mathrm{m}^{-2}\right)$ and Atlantorchestoidea brasiliensis (4.9 org. $\mathrm{m}^{-2}$ ) represent 14 and $2.7 \%$ of the total macrofauna density of this beach, respectively. On the other hand, Navegantes harbors a greater number of species (18) and is dominated numerically by the polychaetes Scolelepis sp. (307.3 org. $\left.\mathrm{m}^{-2}\right)$ and Euzonus furciferus (139.7 org. $\left.\mathrm{m}^{-2}\right)$ and by the bivalve Donax hanleyanus (105.5 org. $\mathrm{m}^{-2}$ ). Together, these three species represent 79.8 $\%$ of the total macrofauna density of this beach. Brava beach harbors a total of 11 species, composed mainly of E. braziliensis $\left(96.6 \mathrm{org} . / \mathrm{m}^{2}\right)$, E. brasiliensis $(22.7$ org. $\left./ \mathrm{m}^{2}\right), \quad$ A. brasiliensis $\left(9.7\right.$ org. $\left./ \mathrm{m}^{2}\right)$ and $D$. hanleyanus $\left(5.4 \mathrm{org} . / \mathrm{m}^{2}\right)$ that together represent about $95 \%$ of the total abundance of this beach (ALVES, 2004).

The local tides are semidiurnal with a mean range of $0.8 \mathrm{~m}$ and a maximum range of $1.2 \mathrm{~m}$. Moreover, meteorological tides exert an important role on the sea level because storm surges can raise it at least $1 \mathrm{~m}$ above the astronomical tide (SCHETTINI et al., 1999). Due to the temperate climate that characterizes the region (NOBRE et al., 1986), the sea water temperature presents a marked seasonality, with the coldest values $\left(14\right.$ to $16^{\circ} \mathrm{C}$ ) occurring in winter and the warmest ones $\left(24\right.$ to $29.5^{\circ} \mathrm{C}$ ) in summer (ALVES et al., 2004).

Northeasterly winds are predominant throughout the year, but southwesterly winds occur in winter and spring associated with the arrival of cold fronts (NOBRE et al., 1986). This meteorological system favors the development of coastal storms with high wave energy that can induce intensive morphological changes on southern Brazilian sandy beaches (KLEIN; MENEZES, 2001). South-southeast waves are the most severe in terms of significant wave heights ranging from 1 to $3.5 \mathrm{~m}$ and peak periods from 4 to 8 s (ALVES; MELO, 2001).

Sampling and Laboratory Procedures

The data used in the present work were obtained, between March 2000 and March 2001, by monthly samplings on beaches with morphodynamic extremes and bimonthly samplings on the beach with intermediate state. All samplings were carried out during spring low tides on transects located in the central part of each beach (Fig. 1) to reduce the possible influence of rocky promontories and/or other physical obstacles present at the extremities of the beaches on their hydrodynamic and morphodynamic conditions.

On each transect, the beach profile was divided into equally spaced sampling strata (levels), from the dunes to the lower limit of the swash zone (Fig. 1). The upper limit of the transects on each beach was determined from a fixed reference point (RN) (Fig. 2) to maintain the spatial correspondence between the stations at all sampling times.

At each sampling level, five $0.03 \mathrm{~m}^{2}$ macrofaunal samples were randomly taken with a plastic cylinder to $20 \mathrm{~cm}$ depth, in an area of $5 \times 12 \mathrm{~m}$. The sediment retained in each sample was sieved through a $0.5 \mathrm{~mm}$ mesh and fixed in $4 \%$ formalin. The animals were identified and counted in the laboratory. Ten quadrats of $2.25 \mathrm{~m}^{2}$ were randomly taken at each station to count Ocypode quadrata burrows.

The following environmental conditions were measured on all sampling dates on the beaches studied: beach morphology, mean grain size and sorting, water content of sediment (moisture levels), water table depth and the position of swash zone and drift line.

Beach morphology was determined by the method described by Birkemeier (1981). To permit the comparison between consecutive profiles, all surveys were taken based on a fixed reference point located at the base of the dunes on each beach (RN) (Fig. 2). The morphological data were used to compute the mean annual sediment reworking that benthic macrofauna experience on different beach levels, which corresponded to standard deviation of the heights measured at each sampling station throughout the study period.

One sand sample was collected at each station with a corer $5 \mathrm{~cm}$ in diameter taken to $10 \mathrm{~cm}$ depth for grain size analysis. Samples were sieved at intervals of 0.5 phi and the method proposed by Folk and Ward 
(1957) was used to determine the statistical parameters (expressed as phi $=-\log _{2}$ of particle diameter $(\mathrm{mm})$ ). For sediment moisture content determination, three replicates were obtained at each sampling station with a $4 \mathrm{~cm}$ diameter corer taken to a depth of $5 \mathrm{~cm}$. The sediment water content was estimated by the weight loss of the sediment after drying at $50^{\circ} \mathrm{C}$ until the weight of the sample stabilized.

Holes were excavated at each sampling station to measure the water table depth. Because of the specifications of the equipment used to excavate, this variable was not obtained at depths greater than $1.5 \mathrm{~m}$.

The position of the drift line (corresponding to the upper limit of the last high tide) and those of the lower and upper limits of the swash zone were determined at each sampling time, by measuring their distance in meters from the beginning of the beach profile (X1) (Fig. 2).

\section{Data Analysis}

The average zonation pattern of the benthic macrofauna was analyzed for each beach, using kite diagrams which were constructed based on the average densities of the species obtained at each sampling station during the study period. The mean data for beach morphology, sediment moisture content and swash zone limits were plotted on these diagrams to enable better interpretation of the distribution patterns of the species.

The average faunistic zones for each beach were identified by cluster analyses (Q Mode). The dissimilarity among the different sampling stations was estimated by the Bray-Curtis coefficient, using the $4^{\text {th }}$ root-transformed mean abundance of species at each sampling station. Dendrograms were constructed based on Unweighted Pair-Group Mean Cluster Analysis (UPGMA) (LEGENDRE; LEGENDRE, 1998) and a level of dissimilarity of 0.5 was adopted for the definition of the groups. The PRIMER program (Plymouth Routines In Multivariate Ecological Research) was used to carry out these analyses (CLARKE; WARWICK, 1994). According to Jaramillo et al. (1993), a valid faunistic zone should include the centre of gravity (or distribution) of at least one characteristic species from this zone. Thus, groups of sampling strata (or a single stratum) that were separated by the cluster analyses because the low densities of certain species were not considered as a faunistic zone per se. Species with a sporadic frequency of occurrence (e. $g$. registered only on a single sampling date for the intermediate beach and no more than two dates for beaches with morphodynamic extremes) were excluded from the analyses. The faunistic zones were identified by letters corresponding to each beach ( $\mathrm{N}$ for Navegantes, $\mathrm{B}$ for Brava and $\mathrm{T}$ for Taquaras), and by numbers indicating their sequential location from the dunes to the sea.

In order to identify the abiotic factors responsible for the spatial variability of the mean zonation patterns of the benthic macrofauna throughout the study area (between beaches), Canonical Correspondence Analyses (CCA) were carried out for the three beaches together, using a biotic matrix constructed based on the mean densities of the species for each sampling station.

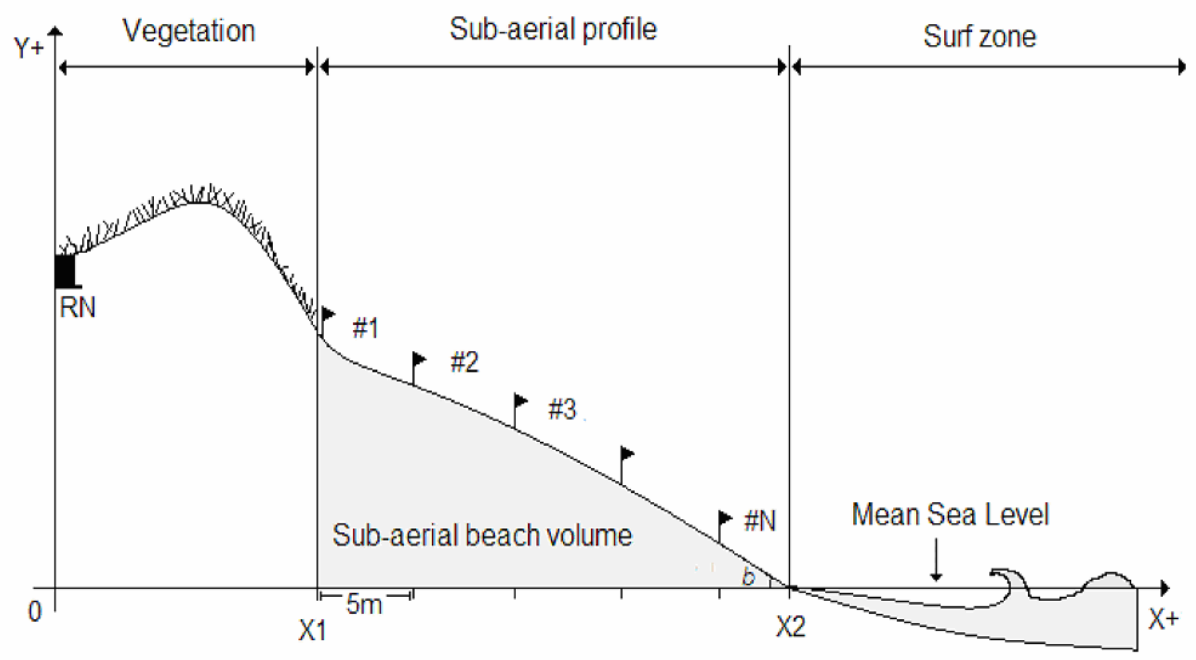

Fig. 2. Sampling scheme. RN: fixed reference point; \#- sampling station; X1: landward boundary corresponding to the first sampling station. Landward boundary is constant per profile and its location was determined from $\mathrm{RN}$; X2: seaward boundary during spring low tides; b: beach slope. 
In the construction of the abiotic matrix, the following environmental factors were considered for each sampling station: mean grain size and sorting, moisture content of the sediment and sediment reworking. The water table depth and the height (quota) of each collection station were not considered in the analysis, as there was significant correlation $(\mathrm{P}<0.05)$ between these and the moisture content of the sediment, making these data redundant. This last variable was selected due to its greater importance for the benthic macrofauna (JARAMILLO et al., 1993). The mean values of the biotic and abiotic variables were calculated for the entire study period (March/2000 to March/2001).

To minimize the number of abiotic factors with maximum explanatory power, the environmental variables were selected, through prior CCA, using the permutation test of Monte Carlo (forward selection procedure) (TER BRAAK, 1988). Thus, only the variables where $\mathrm{P}<0.01$ were included in a subsequent CCA. The abiotic data were standardized by the formula $\mathrm{Y}=\left(\mathrm{X}-\mathrm{X}_{\mathrm{med}}\right) / \mathrm{S}_{\mathrm{x}}$, where $\mathrm{Y}$ : standardized variable; $\mathrm{X}$ : non-standardized variable; $\mathrm{X}_{\text {med }}$ : average value of the variable; $S_{\mathrm{x}}$ : standard deviation of the variable. This analysis was carried out using the CANOCO 3.12 program (TER BRAAK, 1988). The biotic data were transformed by the square root.

\section{REsUlts}

Environmental Characterization

The beaches studied were characterized by distinct cross-shore gradients of mean grain size, water table depth, water content of sediment and sediment reworking. The accretion-erosion dynamics or sediment reworking increased across the dissipativereflective continuum and tended to be concentrated at lower levels of the beach profile in this latter state (Fig. 3). The mean grain size increased from the dissipative to the reflective extreme, and tended to increase downshore on the three beaches studied. All the beaches were characterized by moderately well sorted to well sorted sands, and sorting tended to decrease towards the sea (Table 1).

The different sediment and morphological features of the beaches studied have led to distinct characteristics in relation to water table depth and moisture content of the sediment. On Navegantes, due to the gentler slope profile, a high water table was present, and was less than $20 \mathrm{~cm}$ below the surface of the sediment throughout most of the beach profile. By contrast, a deeper water table was observed for Taquaras due to its steeper slope profile. On this beach, the mean water table depth increased sharply from the sea to the dunes, and was more than $150 \mathrm{~cm}$ deep along most of the profile. Brava beach presented intermediate depths for this variable (Table 1).

On the dissipative beach, high moisture levels were observed along most of the profile due to its fine sediment and high-water table. On the reflective beach, high moisture levels were observed only in the swash zone as a result of the coarser sediment and deeper water table (Table 1).

Mean Zonation of Benthic Macrofauna

The mean number of faunistic zones did not vary across the morphodynamic gradient, with a total of 3 zones being identified for each beach. However, the mean extension and specific composition of these zones varied throughout the study area (Figs 4 to 6).

On Navegantes, the mean zonation pattern was characterized by the existence of overlapping in the distribution of species, and the occurrence of a single species in more than one faunistic zone (Fig. 4). The upper zone (N1) was located near the mean drift line and was characterized by reduced moisture levels $(<5 \%)$ and by the presence of Ocypode quadrata, Atlantorchestoidea brasiliensis and Excirolana braziliensis. The second zone (N2) was located between the mean drift line and the mean upper swash zone limit, and was characterized by the presence of Excirolana armata, Euzonus furciferus, Scolelepis sp. and Donax hanleyanus, and by moisture levels of between 5 and $20 \%$. The lower levels of the beach profile, corresponding to the swash zone, constituted the third faunistic zone (N3) and was characterized by Emerita brasiliensis, Lepidopa richmondi, Bowmaniella brasiliensis, Puelche sp., Phoxocephalopsis zimeri, Bathyporeiapus ruffoi, Donax gemmula, Macrochiridotea giambiageae and Austinixa patagoniensis. The highest number of species and the greatest mean extension were observed for the lower zone (N3) of Navegantes beach. By contrast, the zone formed by $O$. quadrata, $A$. brasiliensis and E. braziliensis (N1) was restricted to the upper few meters of this beach profile (Fig. 4). 

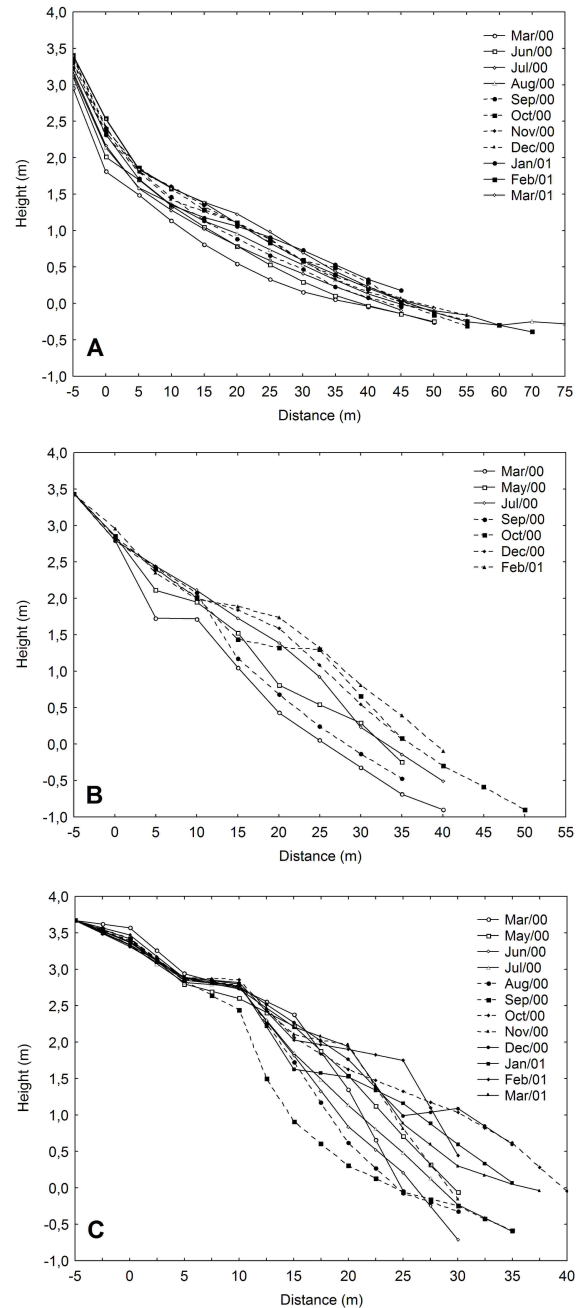

Fig. 3. Subaerial beach morphology of Navegantes (A), Brava (B) and Taquaras (C), recorded between March/2000 and March/2001. Distance "0": landward boundary corresponding to the first sampling station.

Table 1. Mean annual values of grain size (MG), sorting (Sort), water table depth (WD) and water content of sediment (WC) along the subaerial profile of Navegantes, Brava and Taquaras Beaches. Values between brackets are standard errors; Dist: distance from the dunes. $* W D>150 \mathrm{~cm}$

\begin{tabular}{|c|c|c|c|c|c|c|c|c|c|c|c|c|c|c|c|}
\hline Ditim) & $\frac{\mathrm{N} w \mathrm{eg}}{0.5}$ & $\frac{510}{5.10}$ & $10-15$ & $15 \cdot 20$ & 20.25 & $25-30$ & 30.35 & $35-40$ & $40-45$ & 45.50 & $50-56$ & 5660 & $60-66$ & $65 \cdot 70$ & $30-75$ \\
\hline $\mathrm{MG}($ thij & 2.545 & $(0.017)$ & $25 \infty 0$ & $(0023)$ & 2568 & $(0.027)$ & 2545 & $(0003)$ & $250 \%$ & (00031) & 2.457 & $(0.003)$ & 2395 & $(0.055)$ & $250000)$ \\
\hline Sort(phia) & 0364 & (0005) & 0.373 & $(0005)$ & 0.405 & $(0008)$ & 0.432 & $(0010)$ & 0.433 & (0.015) & 0.485 & $(0.017)$ & 0.520 & $(0.04)$ & $0.50000)$ \\
\hline $\mathrm{WD}(\mathrm{m})$ & $110(3.6)$ & $89 \quad(43)$ & $m \quad\langle 48\rangle$ & $\begin{array}{ll}56 & (5.5)\end{array}$ & $46 \quad(5.3)$ & $32 \quad(37)$ & $20 \quad(29)$ & $11 \quad$ (2.1) & $7 \quad(1.8)$ & $5 \quad(16)$ & $3 \quad(15)$ & $2(1.3)$ & $2\langle 1,0\}$ & $0 \quad(0.0)$ & $0\langle 00\rangle$ \\
\hline we (\%) & $3.67(0.78)$ & $439(0.79)$ & $693(154)$ & $11.57(1.76)$ & $13.51(1.49)$ & $1795(0,33)$ & $1924(031)$ & $20.82(0.82)$ & $\begin{array}{c}21.16 \\
\langle 0.61\rangle\end{array}$ & $2127(0.41)$ & $\begin{array}{r}2269 \\
\langle 0.80\rangle\end{array}$ & $2288(090)$ & $\begin{array}{l}21.72 \\
0006\rangle\end{array}$ & $25 s \$\{2.41\}$ & $28.44(0.0)$ \\
\hline Distim) & 0.5 & 5.10 & 10-15 & 15.20 & $20-25$ & 25-30 & $30-35$ & $35-40$ & $40-45$ & 45.50 & $50-56$ & $56 \cdot 60$ & 60.65 & 65.70 & $x-75$ \\
\hline MG (thi) & 1.01 & $(0.013)$ & 1856 & $(0.024)$ & 1907 & $(0.033)$ & 1886 & $(0.069)$ & 1730 & $(0000)$ & 1380 & $(00)$ & & & \\
\hline Sortiphlait) & 0.416 & $(0006)$ & 0336 & $(0007)$ & 0396 & $(0.016)$ & 0.437 & $\{0022\}$ & 0550 & (0.085) & 0.000 & $(000)$ & & & \\
\hline $\mathrm{WD}$ (a) & - & - & $133(50)$ & $116(9.9)$ & 22 (11.5) & $90(12.4)$ & $10 \quad(0.4)$ & $5 \quad$ (3.2) & $5 \quad(22)$ & $\begin{array}{ll}0 & (0.0)\end{array}$ & 0 & $(0.0)$ & & & \\
\hline wC(\%) & $099(028)$ & $136(0.55)$ & $257(0.73)$ & $2.81(0.79)$ & $7.57\{2.41\}$ & $9.71\{2.71\}$ & $1500(2,04\}$ & $18.43(131)$ & $1784\{0,0\}$ & $18.12\{0.0\}$ & & $6(0.0)$ & & & \\
\hline & Ta & & & & & & & & & & & & & & \\
\hline $\begin{array}{l}\text { Ditimi } \\
\text { MGGinhil }\end{array}$ & 0.5 & 5.10 & $10-15$ & 15.20 & ${ }^{20-25}$ & $25 \cdot 30$ & 30.35 & $35-40$ & 30-6 & 45.50 & 50.55 & $55 \cdot 60$ & 60.65 & 6670 & $70-75$ \\
\hline Sortiphlat) & $0.417(0.005)$ & $\begin{array}{l}0.723(0.02017) \\
0.436(0.009)\end{array}$ & $\begin{array}{l}0.91(0.033) \\
0.504(0.017)\end{array}$ & $\begin{array}{l}0.717(0.055) \\
0.446(0.025)\end{array}$ & $\begin{array}{l}0.709(0.064) \\
0.440(0.030)\end{array}$ & $\begin{array}{l}0.723(0046) \\
0.428(0019)\end{array}$ & $\begin{array}{l}0586(0007) \\
0.467(0025)\end{array}$ & $\begin{array}{c}0.525(0.104) \\
0550(0.0)\end{array}$ & & & & & & & \\
\hline $\operatorname{WD}(\mathrm{m})$ & - & . & - & $125(0.2)$ & $76 \quad(06)$ & $36(1.3)$ & is (2.1) & $\begin{array}{ll}0 & (0.0)\end{array}$ & & & & & & & \\
\hline $\mathrm{wC}_{0}(\%)$ & $0.41(0.12)$ & $0.74(0.20)$ & $098(021)$ & $1.97(032)$ & $4.47(1,30)$ & $1020(1.85)$ & $\mathrm{B} 3.61(1.25)$ & $18.11(0.10)$ & & & & & & & \\
\hline
\end{tabular}


At Brava beach, the stations located above the upper mean swash zone limit constitute the first faunistic zone (B1). It was characterized by the presence of $O$. quadrata, A. brasiliensis and Excirolana braziliensis, and by sediment moisture levels ranging from 0 to $13 \%$ (Fig. 5). The second faunistic zone (B2) was characterized by $E$. brasiliensis, D. hanleyanus and L. richmondi, and corresponded to the mean swash zone, where high sediment moisture levels (over $15 \%$ ) were observed.
The cluster analysis revealed a third faunistic zone (B3), located below the mean lower swash zone limit and characterized by the isopod $M$. giambiageae (species that occurs in the infralittoral zone, but its distribution extends to the lower midlittoral zone). The group formed by $O$. quadrata, A. brasiliensis and $E$. braziliensis comprised the wider faunistic zone of this beach (Fig. 5).
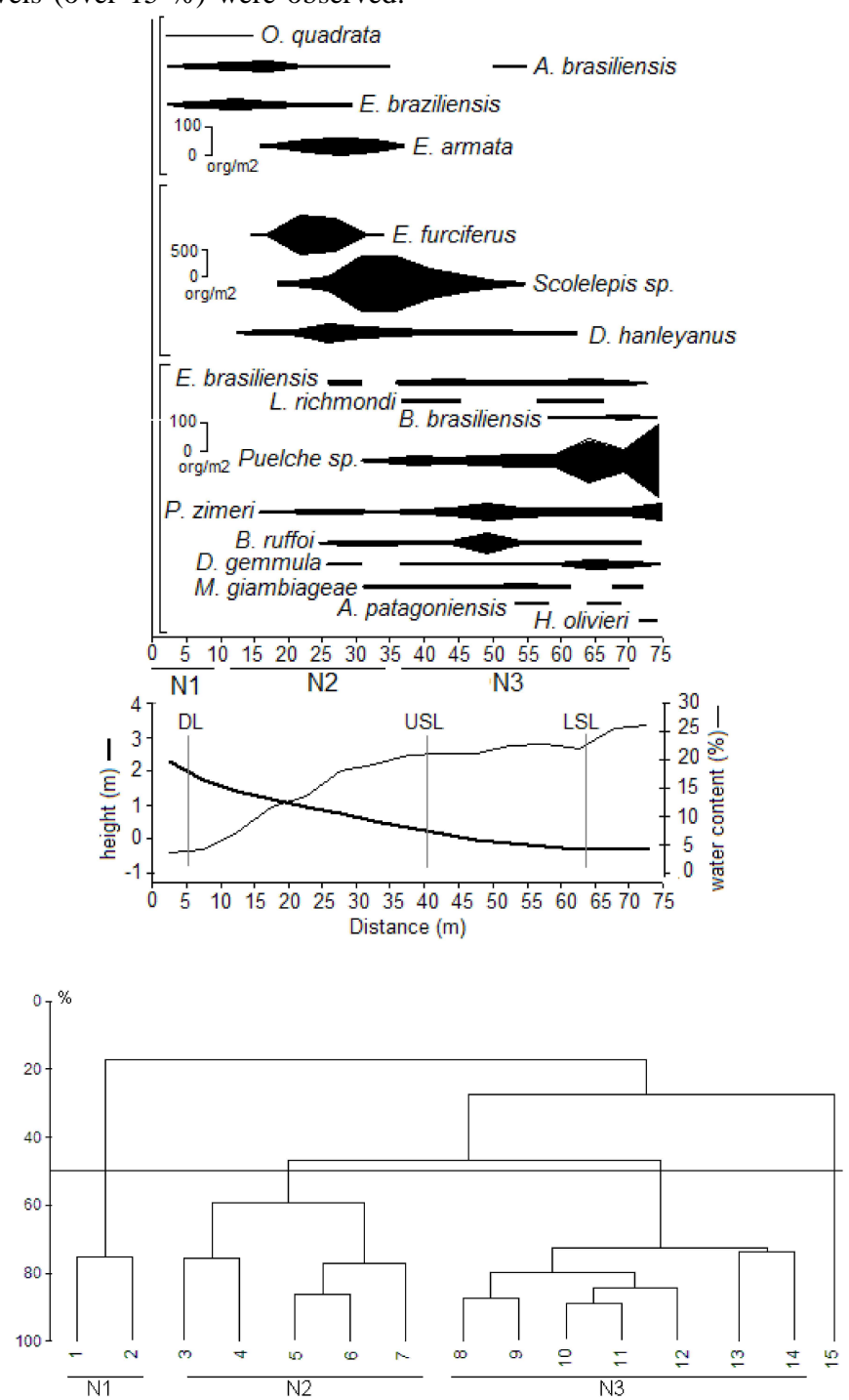

B

Fig. 4. Mean macrobenthic zonation, beach morphology and moisture content at Navegantes beach (A), and the cluster analysis results (B). DL: mean drift line; USL: mean upper swash limit; LSL: mean lower swash limit. Distance "0": landward boundary corresponding to the first sampling station. 

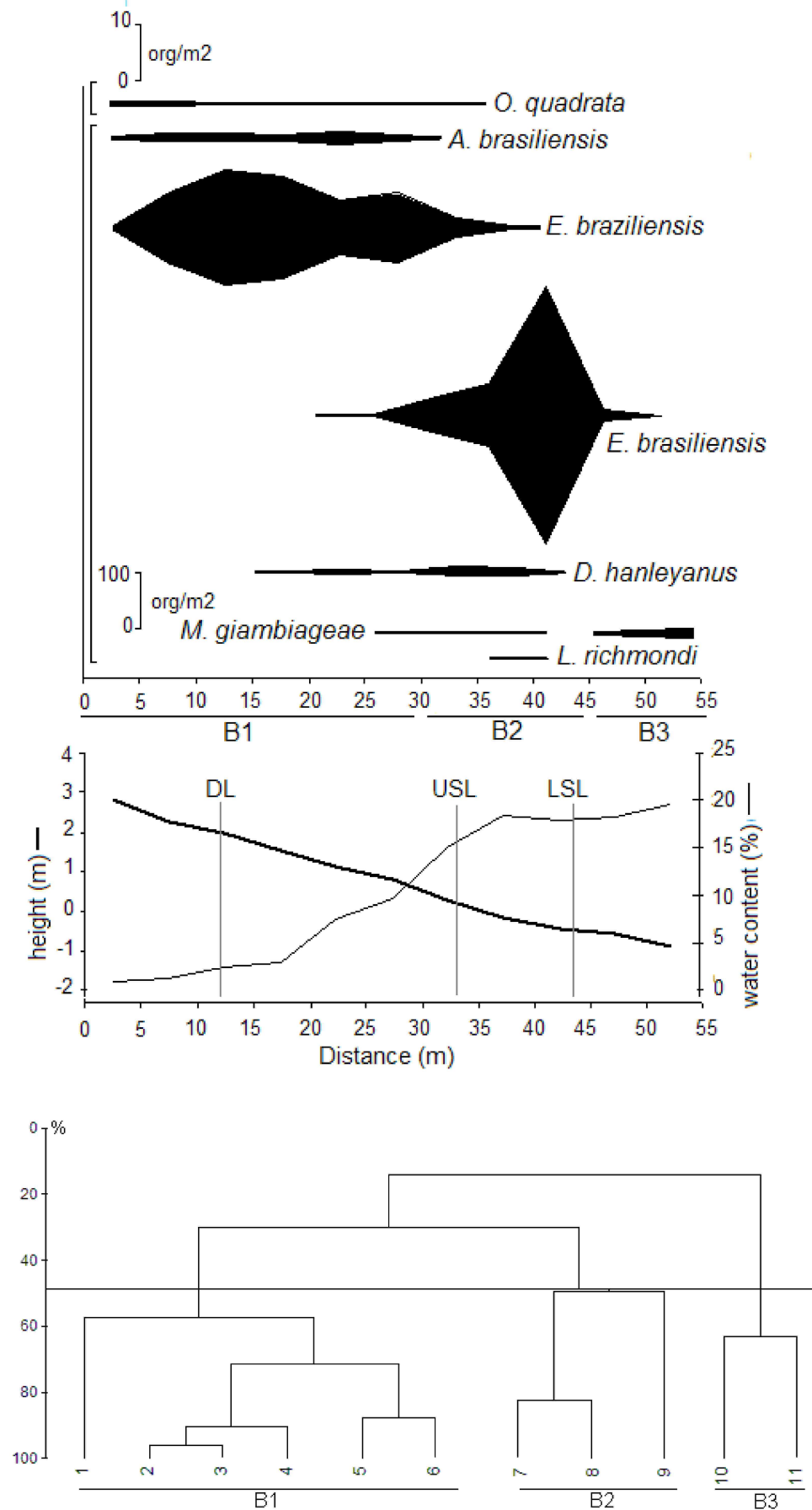

B

Fig. 5. Mean macrobenthic zonation, beach morphology and moisture content at Brava beach (A), and the cluster analysis results (B). DL: mean drift line; USL: mean upper swash limit; LSL: mean lower swash limit. Distance "0": landward boundary corresponding to the first sampling station. 


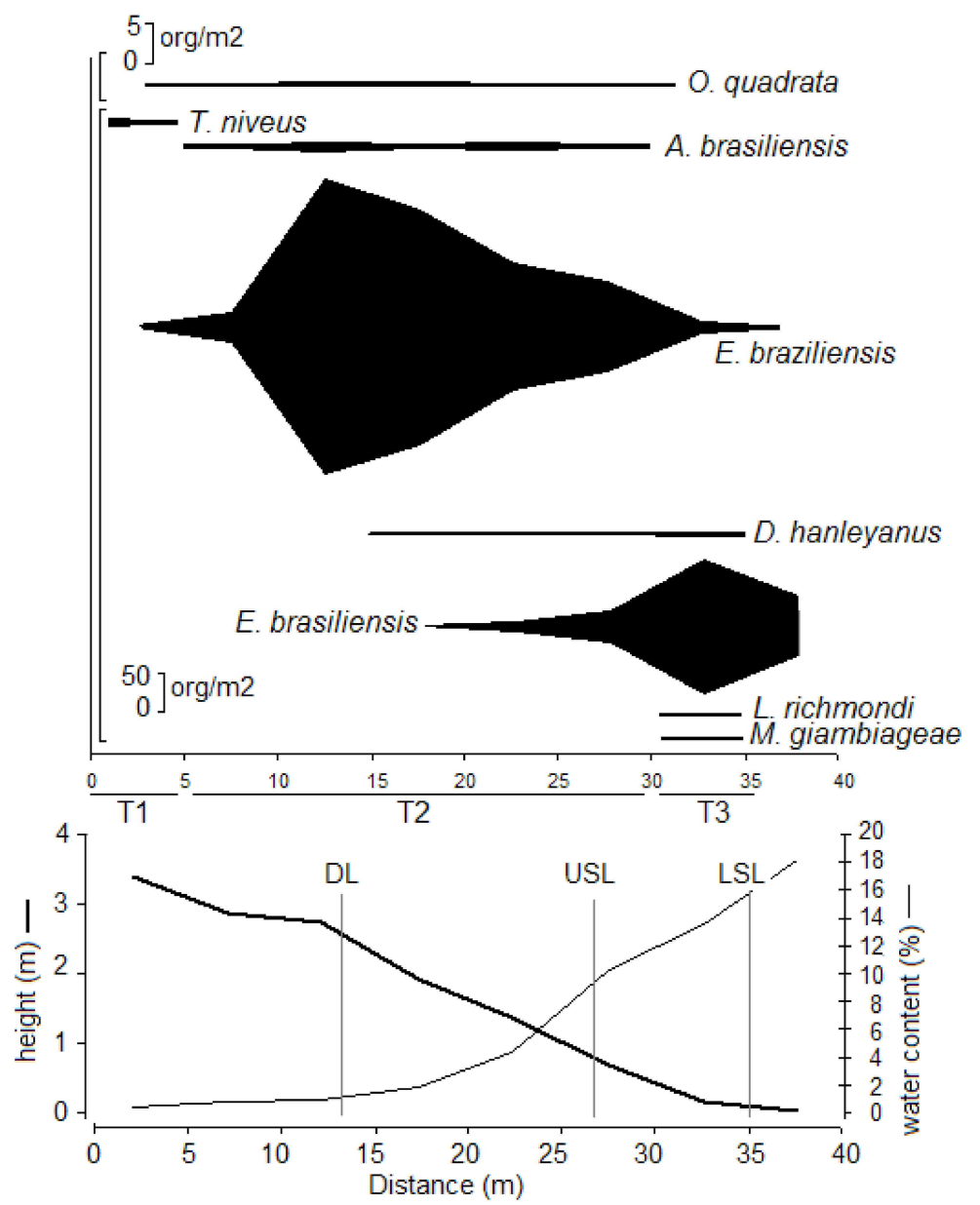

A



B

Fig. 6. Mean macrobenthic zonation, beach morphology and moisture content at Taquaras beach (A), and the cluster analysis results (B). DL: mean drift line; USL: mean upper swash limit; LSL: mean lower swash limit. Distance "0": landward boundary corresponding to the first sampling station. 
Table 2. Results of Canonical Correspondence Analysis and Monte Carlo test, applied for the three beaches together. Corr. spp x env: correlation between species and environmental variables; Cum. Var: cumulative variance for the first three axis (A); spp: species; env: environmental variables.

\begin{tabular}{|c|c|c|c|}
\hline & A1 & $\mathbf{A 2}$ & $\mathbf{A 3}$ \\
\hline Eigenvalues & 0,694 & 0,271 & 0,098 \\
\hline Corr. spp x env & 0,981 & 0,791 & 0,580 \\
\hline \multicolumn{4}{|l|}{ Cum. Var (\%): } \\
\hline spp & 30,2 & 42,0 & 46,3 \\
\hline spp x env & 65,3 & 90,8 & 99,2 \\
\hline \multicolumn{4}{|c|}{ Monte Carlo Test } \\
\hline & & $\mathbf{p}$ & Inertia \\
\hline moisture levels & & 0,005 & 0,69 \\
\hline mean grain size & & 0,005 & 0,27 \\
\hline sediment reworking & & 0,005 & 0,10 \\
\hline sediment sorting & & 0,060 & --- \\
\hline Total inertia & & \multicolumn{2}{|c|}{1,16} \\
\hline
\end{tabular}

On Taquaras, the first faunistic zone (T1) was located far above the mean drift line. It was characterized by the isopod Tylos niveus and by very low sediment moisture levels $(<2 \%$ ) (Fig. 6). The second faunistic zone (T2), was located between the mean upper swash zone limit and the mean drift line. It was characterized by sediment moisture ranging from 2 to $10 \%$ and by the presence of $O$. quadrata, $A$. brasiliensis and E. braziliensis (Fig. 6). The lower levels of Taquaras beach, corresponding to the swash zone, comprise the third faunistic zone (T3) characterized by high sediment moisture levels (12 to $18 \%$ ) and by the presence of $E$. brasiliensis, D. hanleyanus, L. richmondi and $M$. giambiageae. It should be emphasized that although the cluster analysis identified the formation of a group with station 8 (Fig. 6B), this did not comprise a faunistic zone per se, being characterized by low densities of $E$. brasiliensis (Fig. 6A). The faunistic zone comprising $O$. quadrata, A. brasiliensis and E. braziliensis was the widest zone of this beach.

Relationship Between Zonation and Environmental Factors

The moisture content of the sediment, grain size and sediment reworking were the main environmental factors responsible for the alterations observed for the zonation patterns of the species throughout the study area, and were selected by the Monte Carlo test. Of the environmental variables considered in this analysis, only the sorting of sediment was not selected (Table 2).
For the three beaches, the sampling stations on the lower levels of the beach profile were gradually replaced, along Axis 1, by the stations on the upper levels, showing a close relationship with the moisture gradient (Fig. 7). Likewise, species associated with reduced moisture levels occurred in the right quadrant of the diagram, while those related to high moisture levels occurred in the left sector of the graph, following the moisture gradient represented by Axis 1 (Fig. 8).

The Canonical Correspondence Analysis also revealed that the main differences in zonation throughout the study area were related to the lower beach levels. A clear separation was observed between the sampling stations of the lower levels of Taquaras, Brava and, in particular, Navegantes. On the other hand, stations on the higher levels of the three beaches were mainly clustered on the right of Axis 1 (Fig. 7). On Navegantes, the stations on the lower beach levels were related to a higher number of species, higher moisture levels, reduced sediment reworking and fine sediment. The lower levels of the Brava and Taquaras beaches were associated with lower moisture levels, larger grain sizes, and higher sediment reworking (Figs 7 and 8). Furthermore, they harbored a lower number of species. The cluster of stations on the upper levels of the three beaches in the lower right sector of the graph (Fig. 7), revealed that the distribution of the species associated with this region (Fig. 8) is conditioned by similar environmental factors, that which are prevalent throughout the morphodynamic continuum, i.e. reduced moisture content. 


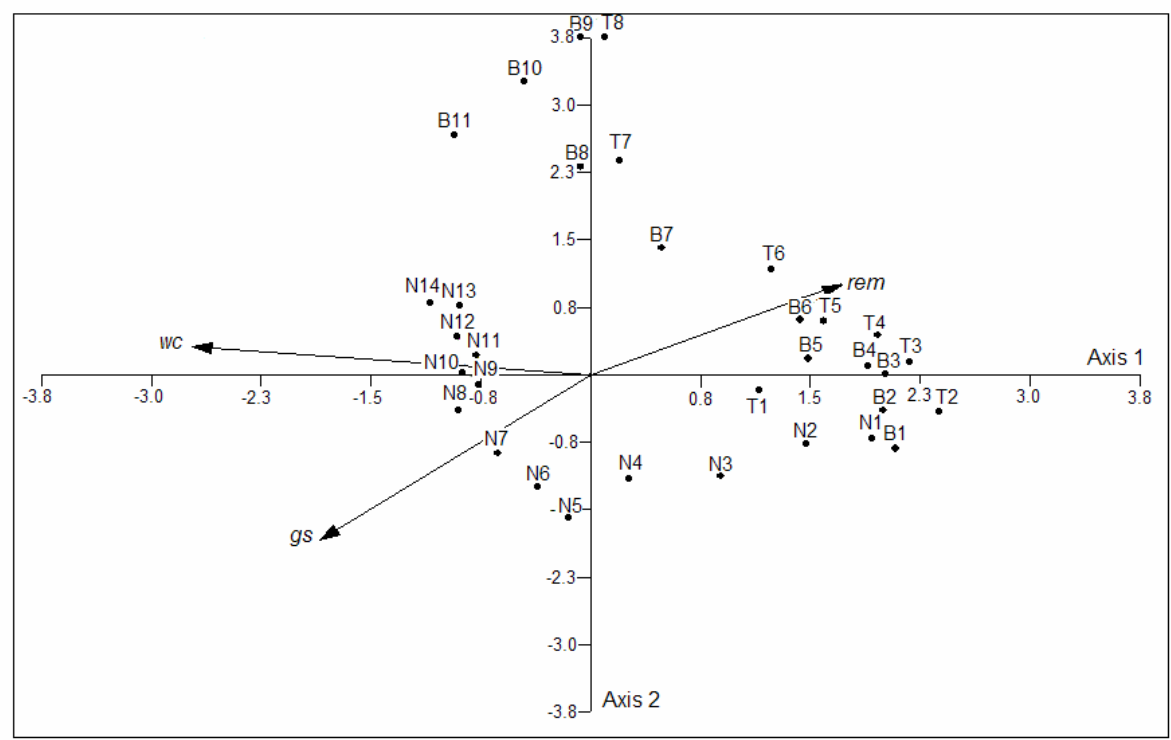

Fig. 7. Results of the Canonical Correspondence Analysis based on environmental variables and sampling stations at Taquaras (T), Brava (B) and Navegantes $(\mathrm{N})$ beaches. $w c$ : water content of the sediment; gs: mean grain size; rem: sediment reworking; sampling stations are labeled from dunes towards the sea.

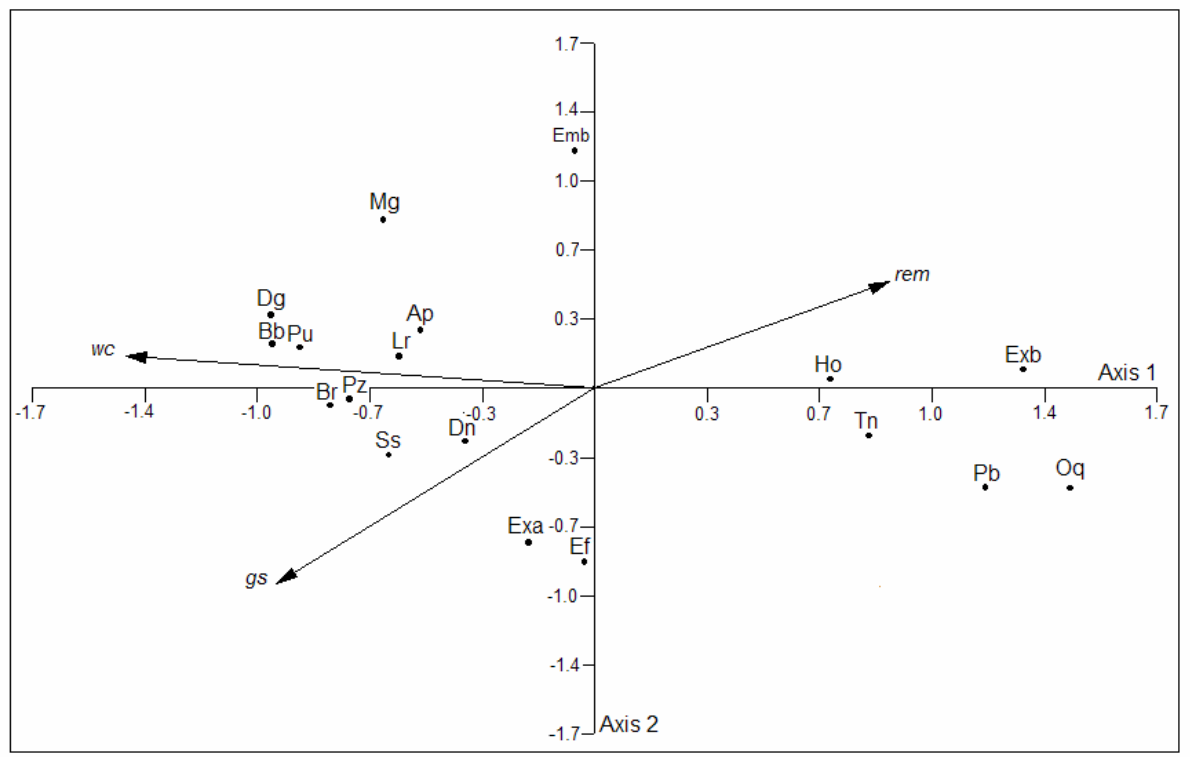

Fig. 8. Results of the Canonical Correspondence Analysis based on environmental variables and species sampled at Taquaras (T), Brava (B) and Navegantes (N) beaches $w c$ : water content of the sediment; gs: mean grain size; rem: sediment reworking; Tn: T. niveus; Oq: O. quadrata; Ab: A. brasiliensis; Exb: E. braziliensis; Exa: E. armata; Ef: E. furciferus; Ss: Scolelepis sp.; Ho: Hemipodus olivieri; Dh: D. hanleyanus; Emb: E. brasiliensis; Pz: P. zimeri; Br: B. ruffoi; Lr: L. richmondi; Pu: Puelche sp.; Bb: B. brasiliensis; Dg: D. gemmula; Ap: A. patagoniensis; Mg: M. giambiageae. 


\section{Discussion}

Consistent differences in the average zonation pattern of the benthic macrofauna were observed across the morphodynamic spectrum on exposed sandy beaches of Santa Catarina, essentially differing in relation to the composition and extension of the faunistic zones. Considering that latitudinal variations and exposure to wave action do not constituted factors of variability in this study, the results obtained indicate that the cross-shore environmental gradients associated with the morphodynamic spectrum induced the different zonation patterns observed throughout the study area. According to the Canonical Correspondence Analysis, these differences mainly resulted from distinctive cross-shore gradients of moisture level, sediment reworking and grain size that exists across the morphodynamic spectrum.

The faunistic zone characterized by the crustaceans $O$. quadrata, A. brasiliensis and $E$. braziliensis was common to the three beaches studied. However, this zone represented $71 \%$ of the beach profile in the reflective state, and decreased gradually towards the dissipative extreme, where it was restricted to just $14.3 \%$ of the beach profile. For practically the entire study period, its location and extension coincided with the regions characterized by moisture levels lower than $5 \%$ on all the beaches (ALVES, 2004), confirming the preference and/or tolerance of these species for sediments with reduced moisture levels.

In Taquaras, the extension of the faunistic zone corresponding to the mean swash zone, comprised of E. brasiliensis, D. hanleyanus, $L$. richmondi and $M$. giambiageae represented $14 \%$ of the beach profile. These same species formed two distinct zones on Brava beach, corresponding to the mean swash zone (E. brasiliensis, D. hanleyanus, L. richmondi) and the portion immediately below it (M. giambiageae), which together represented around $45 \%$ of the total extension of this beach profile. On Navegantes, the extension of the faunistic zone corresponding to the mean swash zone (E. brasiliensis, L. richmondi, $B$. brasiliensis, Puelche sp., P. zimeri, B. ruffoi, D. gemmula, M. giambiageae, A. patagoniensis and $H$. olivieri) represented $50 \%$ of the profile. Moreover, on this beach, the greater extension of the high moisture zone also led to the occurrence of a biological zone comprised of E. furciferus, E. armata and $D$. hanleyanus, located above the mean upper swash zone limit, and corresponding to $33 \%$ of the beach profile.

In other words, although certain species characterized the upper levels (O. quadrata, $A$. brasiliensis, E. braziliensis) and lower levels of the profile (E. brasiliensis, L. richmondi, etc.) in all the beaches studied (which agrees, in general, with the zonation scheme proposed by Dahl (1952), the average extension of their distribution varied according to the distinct moisture gradients coupled with each morphodynamic state. The zone formed by species which occur preferentially in places characterized by low moisture levels increased in extension to the reflective extreme, following the increase in extension of the zones with low moisture levels. On the other hand, the lower zone or zones inhabited by species which prefer high sediment moisture levels increased in extension in the opposite direction, demonstrating that the distribution of each species throughout the beach profile depends primarily on its preference for and/or tolerance of certain sediment moisture levels. These results support the observations of Jaramillo et al. (1993) and McLachlan and Jaramillo (1995), who pointed out the importance of the moisture gradient in the distribution of sandy beach macrofauna, and stressed the need of determining this variable in studies dedicated to understanding the zonation patterns on microtidal sandy beaches.

In a review of general zonation schemes proposed for sandy beach macrobenthos, McLachlan and Jaramillo (1995) conclude that faunistic zones tend to be narrower and clearest at the top of the shore and become increasingly blurred and wide moving downshore. The results obtained in the present study demonstrate that this suggestion does not apply to the entire morphodynamic spectrum. At the reflective extreme, a greater extension was observed for the faunistic zone located at the top of the shore. Likewise, all the biological zones were clearest in this beach type than in the dissipative state, where a greater overlapping between zones was observed, particularly at the lower levels of the beach profile.

The increasing overlapping between biological zones observed towards the dissipative extreme appears to be the result of more gradual horizontal changes in moisture levels across the beach profile. In Taquaras, humidity is not retained by the sediment during low tide because of the presence of coarse sand and the deep water table. On this beach, high moisture levels occur only in the swash zone, leading to marked discontinuities in this parameter throughout the profile and, as a result, in the establishment of clearly and sharply defined faunistic zones at this extreme. On the other hand, on Navegantes the high water table and the presence of fine sand induced more gradual changes in moisture levels across the beach profile. It permitted that species adapted to high moisture levels, should not be restricted to swash zone, but might extend their distribution to upper beach levels, causing a greater overlap of species distribution. The existence of more gradual horizontal changes in moisture levels towards the dissipative extreme, as observed in this study, may explain the less clear zones and zonation patterns 
found by other authors for ultradissipative beaches and tidal plains (RAFAELLI et al., 1991; MCLACHLAN et al., 1996; BORZONE et al., 2003).

Contrary to the findings of other authors (e.g. JARAMILLO; GONZALEZ, 1991; DEFEO et al., 1992; JARAMILLO et al., 1993; JARAMILLO, 1994), who observed a reduction in the number of faunistic zones towards the reflective extreme, in this study the mean number of faunistic zones did not vary through the morphodynamic spectrum. A total of three zones were identified for each beach. However, the composition of species of the lower zones of the beaches varied through the morphodynamic spectrum. The reflective extreme tended to harbor fewer species at the lower beach levels, where only organisms with efficient burrowing capacity were common.

Many works dedicated to studying zonation have observed the exclusion of species in the swash zone towards reflective beaches (e.g. DYE et al. 1981; DEFEO et al., 1992; JARAMILLO et al., 1993; JARAMILLO, 1994; MCLACHLAN; JARAMILLO, 1995; GIMÉNEZ; YANNICELLI, 1997), contributing to the general acceptance of the Swash Exclusion Hypothesis proposed by McLachlan et al. (1993). According to these authors, the swash climate coupled to each beach type is the controlling factor of the benthic macrofauna: the increased harshness of the swash conditions through the dissipative-reflective spectrum (represented by an increase in swash speed and a decrease in swash period and length) excludes an increasing number of intertidal species, so that at the reflective extreme, only supralittoral forms remain.

Differences in the swash conditions were observed for the beaches studied by Alves et al. (2004), and are characterized by a significant reduction in mean swash length and period towards the reflective extreme. The average swash speed did not vary significantly throughout this gradient. However, in this study, a series of other variables suffered pronounced alterations across the dissipative-reflective spectrum, intensifying precisely in the swash zone. Besides an increase in mean grain size, we observed an accentuated increase in sediment reworking and a reduction in the length of the zones with high moisture levels (which restricts the upper distribution of infralittoral species). These results suggest that the differences observed across the morphodynamic spectrum for the species composition in the lower beach zones may be conditioned by any one of these factors, whether in isolation or in combination, as previously proposed by Brazeiro (2001).

Considering the interspecific variability of the benthic macrofauna, and that many physical variables change according to the morphodynamic spectrum and may have independent effects on biological processes and/or species, this author suggested that there is no single key factor which determines the distribution of the species across the morphodynamic spectrum. Brazeiro (2001) proposes the Multicausal Environmental Severity Hypothesis, which suggests that the exclusion of species towards the reflective extreme is caused by an increase in environmental harshness generated by the overall effect of independent factors.

Although the present study has considered only three morphodynamic stages and a single beach in each one, the results obtained corroborate the observations of Brazeiro (2001) and suggest that, on microtidal exposed sandy beaches, the exclusion of species towards the reflective extreme is a result of an increase in environmental severity caused by an independent effect or a combination of the following factors: increase in mean grain size and sediment reworking (accretion-erosion dynamics) and reduction in extension of the zones with high moisture content. We suggest that future studies should test the proposals presented here as applied to a wider range of morphodynamic types, latitudinal gradients and tidal ranges.

\section{Conclusions}

This work identified different environmental gradients across the morphodynamic spectrum of the exposed sandy beaches of Santa Catarina. These gradients induced marked differences in the average zonation pattern of benthic macrofauna along the subaerial profile of the beaches studied. The main differences observed from reflective to dissipative conditions were: a) increase in the number of species in the lower beach zones; b) expansion of zones characterized by high water content of sediment and c) increase in overlap of the faunistic zones, mainly at the lower beach levels. The moisture content of the sediment was the main controlling parameter of the spatial structure of the macrofauna, since it determined the average extension and location of the faunistic zones, based on the preference and/or tolerance of the different species to this variable. The species composition, particularly at the lower beach levels, was determined by an independent effect or a combination of the following factors: moisture content of the sediment, sediment reworking and mean grain size. These results corroborate the observations of other authors, that the morphodynamic state should be considered in zonation studies of the macrofauna, and showed the importance of measuring distinct environmental gradients associated with the morphodynamic spectrum, including the sediment reworking and the water content of sediment, for an understanding of these patterns in exposed sandy beaches. 


\section{AcKNOWLEDGMENTS}

This manuscript is part of the Doctoral Thesis developed by the first author under the supervision of Dr. Sérgio de Almeida Rodrigues (Instituto de Biociências da Universidade de São Paulo - IB/USP) who passed away just before this study was finished. The authors are grateful to Dr. Gisela Y. Shimizu (IB/USP) for her kindly assistance during the last part of the course.

\section{REFERENCES}

ALVES, E. S. O efeito da morfodinâmica praial e suas variações temporais de curto e médio prazo sobre a macrofauna bentônica de três praias arenosas expostas de Santa Catarina, Brasil. 2004. 247 p. Tese (Doutorado) - Instituto de Biociências, Universidade de São Paulo, São Paulo.

ALVES, J. H. G. M.; MELO, E. Measurement and modeling of wind waves at the northern coast of Santa Catarina, Brazil. Revta Bras. Oceanogr., v. 49, n. 1-2, p. 13-28, 2001.

ALVES, E. S.; RODRIGUES, S. A.; PEZZUTO, P. R.; SHIMIZU, G. Y. Caracterização ambiental da porção subaérea de praias arenosas expostas com diferentes características morfodinâmicas no litoral centro-norte de Santa Catarina, Brasil. Notas Téc. FACIMAR, v. 8, p. 1-24, 2004.

BIRKEMEIER, W. A. Fast accurate two-person beach survey. Coast. Engng tech. Aid 81-11, U. S. Army Engineer Waterways Experiment Station, Coastal Engineering Research Center, Mississipi, 1981. 22 p.

BORZONE, C. A.; SOUZA, J. R. B.; SOARES, A. G. Morphodynamics and tropical macrofauna structure. Rev. Chil. Hist. Nat., v. 69, n. 4, p. 565-577, 1996.

BORZONE, C. A.; MELO, S. G.; REZENDE, K. V.; VALE, R.; KRUL, R. Macrobenthic intertidal communities from wave to tide dominated beach environments. A case study in two brazilian beaches. J. coast. Res., Sup. 35, p. 472-480, 2003.

BRAZEIRO, A. Relationship between species richness and morphodynamics in sandy beaches: what are the underlying factors? Mar. Ecol. Prog. Ser., v. 224, p. 35 44, 2001.

BRAZEIRO, A.; DEFEO, O. Macroinfauna zonation in microtidal sandy beaches: is it possible to identify patterns in such variable environments? Estuar. coast. Shelf Sci., v. 42, p. 523-536, 1996.

CLARKE, K. R.; WARWICK, R. M. Change in marine communities: An approach to statistical analysis and interpretation. Plymouth: Plymouth Marine Laboratory, 1994. $144 \mathrm{p}$.

DAHL, E. Some aspects of the ecology and zonation of the fauna on sandy beaches. Oikos, v. 4, n. 1, p. 1-27, 1952.

DEFEO, O.; MCLACHLAN, A. Patterns, process and regulatory mechanisms in sandy beach macrofauna: a multi-scale analysis. Mar. Ecol. Prog. Ser., v. 295, p. 120,2005

DEFEO, O.; JARAMILLO, E.; LYONNET, A. Community structure and intertidal zonation of the macroinfauna on the Atlantic Coast of Uruguay. J. coast. Res., v. 8, n. 4, p. 830-839, 1992.

DYE, A. H.; McLACHLAN, A.; WOOLDRIDGE, T. The ecology of sandy beaches in Natal. S. Afric. J. Zool., v. 16, n. 4, p. 200-209, 1981.

FOLK, R. L.; WARD, W. C. Brazos river bar: a study in the significance of grain size parameters. J. sedim. Petrology, v. 27, n. 1, p. 3-26, 1957.

GIMÉNEZ, L.; YANNICELLI, B. Variability of zonation patterns in temperate microtidal Uruguayan beaches with different morphodynamic types. Mar. Ecol. Prog. Ser., v. 160, p. 197-207, 1997.

JARAMILLO, E. Patterns of species richness in sandy beaches of South America. S. Afric. J. Zool., v. 29, p. 227-234, 1994.

JARAMILLO, E.; GONZALEZ, M. Community structure and zonation of the macroinfauna along a dissipativereflective range of beach category in southern Chile. Stud. neotrop. Fauna Environ., v. 26, n. 4, p. 193-212, 1991.

JARAMILLO, E.; MCLACHLAN, A.; COETZEE, P. Intertidal zonation patterns of macroinfauna over a range of exposed sandy beaches in south-central Chile. Mar. Ecol. Prog. Ser., v. 101, p. 105-118, 1993.

KLEIN, A. H. F.; MENEZES, J. T. Beach morphodynamics and profile sequence for a headland bay coast. J. coast. Res., v. 17, n. 4, p. 812-835, 2001.

KLEIN, A. H. F.; BENEDET FILHO, L.; SCHUMACHER, D. H. Short-term beach rotation processes in distinct headland bay beach systems. J. coast. Res., v. 18, n. 3, p. 442-458, 2002.

LEGENDRE, P.; LEGENDRE, L. Numerical Ecology. $2^{\text {nd }}$ edition. Amsterdam: Elsevier, 1998. 851 p.

MCLACHLAN, A.; JARAMILLO, E. Zonation on sandy beaches. Oceanogr. mar. Biology a. Rev., v. 33, p. 305$335,1995$.

MCLACHLAN, A.; JARAMILLO, E.; DONN, T. E.; WESSELS, F. Sandy beach macrofauna communities and their control by the physical environment: a geographical comparison. J. coast. Res., v. 15, p. 27-38, 1993.

MCLACHLAN, A.; RUYCK, A.; HACKING, N. Community structure on sandy beaches: patterns of richness and zonation in relation to tide range and latitude. Rev. Chil. Hist. nat., v. 69, n. 4, p. 451-467, 1996.

NOBRE, C. A.; CAVALCANTI, M. A. G.; NOBRE, P.; KAYANO, M. T.; RAO, V. B.; BONATTI, J. P.; SATYAMURTI, P.; UVO, C. B.; COHEN, J. C. Aspectos da climatologia dinâmica do Brasil. Climanálise. 1996. Número especial.

RAFAELLI, D.; KARAKASSIS, I.; GALLOWAY, A. Zonation schemes on sandy shores: a multivariate approach. Expl mar. Biol. Ecol., v. 148, p. 241-253, 1991.

SALVAT, M. B. Les conditions hydrodynamiques interstitielles des sédiments meubles intertidaux et la répartition verticale de la faune endogée. Comptes Rendus Acad. Sciences Paris, v. 259, p. 1576-1579, 1964.

SCHETTINI, C. A. F. Caracterização física do estuário do rio Itajaí-açu, SC. Revta.Bras. Recursos hidr., v. 7, n. 1, p. 123-142, 2002. 
SCHETTINI, C. A. F.; CARVALHO, J. L.; TRUCCOLO, E. C. Aspectos hidrodinâmicos da enseada da Armação de Itapocoroy, SC. Notas téc. FACIMAR, v. 3, p. 99-109, 1999.

SHORT, A. Handbook of beach and shoreface morphodynamics. Chichester: John Wiley, 1999. 491 p.

TER BRAAK, C. J. F. CANOCO - a Fortram Program for Canonical Community Ordination. The Netherlands: Ministerie van Landbouw en Visserij. Groep Landbouwwiskunde. Wageningen, 1988, 95 p.
VELOSO, V. G; CARDOSO, R. S. The effect of morphodynamics on the spatial and temporal variation of the macrofauna of three sandy beaches in? the Rio de Janeiro state, Brazil. J. mar. Biol. Assoc. U. K., v. 81, p. 369-375, 2001.

(Manuscript received 04 September 2008; revised 15 December 2008; accepted 24 April 2009) 